\title{
Comparison of Two School Feeding Programmes in Ghana, West Africa
}

\author{
Justina S. Owusu ${ }^{1,2}$, Esi K. Colecraft ${ }^{2}$, Richmond N.O. Aryeetey ${ }^{3}$, Joan A. Vaccaro ${ }^{1}$ and \\ Fatma G. Huffman ${ }^{1, *}$
}

${ }^{1}$ Department of Dietetics and Nutrition, Florida International University, Miami, FL, USA

${ }^{2}$ Department of Nutrition and Food Science, University of Ghana, Legon - Accra, Ghana

${ }^{3}$ School of Public Health, University of Ghana, Legon - Accra, Ghana

\begin{abstract}
Background: Malnutrition of children in Ghana continues during school years. There is limited information on how school meals meet nutrient recommendations in Ghana.

Objectives: The aim of this study was to compare energy and nutrient content of meals served by Ghana School Feeding Programme (GSFP) and Non-Governmental School Feeding Programme (NGSFP) and adherence to nutrient recommendations.

Methods: This was a cross sectional study design involving observation of school meals at two sites: GSFP and NGSFP. Average weights of a week's meal were converted to energy and nutrient equivalence and compared with international recommendations. Differences assessed with $t$-tests.

Results: NGSFP provided significantly higher portion size ( $416 \pm 96 \mathrm{~g}$ vs. $243 \pm 50 \mathrm{~g} ; \mathrm{p}=0.007)$, energy $(776 \pm 427 \mathrm{kcal}$ vs. $315 \pm 24 \mathrm{kcal} ; \mathrm{p}=0.042)$ and fats $(17 \pm 8$ vs. $6 \pm 2 ; p=0.019)$ but similar micronutrient contributions to GSFP. NGSFP met energy and macronutrient recommendation set by World Food Programme; whereas, GSFP did not meet the recommendations.

Conclusion and Recommendations: The NGSFP had more energy and macronutrients per serving size than the GSFP. Regulation of meals served by GSFP should be reviewed to ensure they contribute to the adequacy of children's diets as well as meet recommendations set by World Food Programme.
\end{abstract}

Keywords: Malnutrition, school breakfast and lunch programmes, nutritional value, diet diversity, Ghana.

\section{BACKGROUND}

Malnutrition among school age children is a public health problem in developing countries [1]. The most commonly reported nutritional problems among school age children include underweight and micronutrient deficiencies of iron, zinc, iodine and vitamin A [1]. While nationwide data on the nutritional status of Ghanaian school age children are currently unavailable, a study in the Eastern region of the country found that $44 \%$ of the 645 rural school age children assessed were stunted and $70 \%$ of them were anaemic [2]. In Ghana $14 \%$ and $28 \%$ of preschool age children are underweight and stunted, respectively [3]. Uncorrected undernutrition in the preschool age years means that many children may be entering school with nutritional deficits [4].School feeding programmes have been established in an effort to lessen hunger and its negative effect on the nutritional status and learning capacity of school age children [5].

\footnotetext{
*Address correspondence to this author at the Department of Nutrition and Dietetics, Robert R. Stempel College of Public Health and Social Work, Florida International University, $11200 \mathrm{SW}, 8^{\text {th }} \mathrm{ST}$, AHC-5 Room 306, Miami, FL 33199, USA; Tel: (305) 348-3788; Fax: (305) 348-1996;
}

E-mail: huffmanf@fiu.edu
Globally, the United Nations World Food programme (WFP) has been supporting implementation of school feeding programmes [5]. School feeding programmes as an intervention contribute to improving the nutritional status of school age children by eliminating hunger in the short term. In a systematic review of school feeding programmes, improvements in weight, height especially in younger children (6-8 years), school attendance, mathematics performance, bone mineral density, arm muscle, concentrations of B-vitamins and behaviour were reported in children participating in school feeding programmes [6].

During the school age period, interventions can be targeted at children to promote catch up with growth and reduce residual effect of malnourishment occurring during the preschool age [4]. The school system is a good platform for delivery of services to improve the health and nutritional status of school children. The Ghana School Feeding Programme (GSFP) was initiated in 2005 under the New Partnership for Africa's Development, 'Home Grown' School Feeding Programme concept [7]. The goal of GSFP was to use locally produced food to feed children in order to reduce poverty and malnutrition by providing a hot 
meal to public primary and kindergarten children. In 2010, GSFP had contributed to $20-25 \%$ increase in enrollment and $90-95 \%$ increase in school attendance and retention [7].

Nutrition statistics in developing countries have focused on children under five years of age and there is limited information about school age children [8]. In Ghana, large-scale evaluation of GSFP has centred on enrolment and attendance; however, there are limited studies on how closely school feeding programmes meet World Food Programme nutritional recommendations for school age children. Therefore, the aim of this study was to evaluate two feeding programmes in Ghana: the Ghana School feeding programme (GSFP) and one run by a nongovernmental organisation (NGSFP). This study compared the diet and nutritive values of meals served under GSFP and NGSFP in two neighbouring semirural communities in Ghana.

\section{METHODS}

The study was conducted in two public schools in neighbouring semi-rural areas and located in the La Nkwatanang Madina Municipal area of the Greater Accra region. The communities were purposively selected because they had similar geographic and socioeconomic characteristics in addition to the presence of a government-based school feeding programme (GSFP) in one community and a nongovernment-based school-feeding programme (NGSFP) in the other community to facilitate comparison between the two types of school feeding programmes.

\section{Data Collection}

Data were collected from January 2013 to April 2013. Meals served to school children at both school feeding programmes sites were weighed over one week period. Seven portions of each meal were weighed prior to consumption. All plates were reweighed after consumption to the nearest $1 \mathrm{~g}$. The average weight of each daily food sample was calculated and used in calories and other selected nutrients computation. Meals served to school children were also documented over a four week period. Informal discussions were conducted on menu with managers of catering units of both school feeding programmes. The research protocol was reviewed and approved by the Institutional Review Board (IRB) of the Noguchi Memorial Institute for Medical Research,
Accra, Ghana (Protocol Number: 012/12-13). Permission to carry out the study at the schools was obtained from Ghana Education Service Directorate at Ga-East Municipal and the heads of the schools.

\section{Data Analysis}

SPSS version 16. 0 was used for data management and analysis. Dietary information was converted to energy and nutrients using the Research to Improve Infant Nutrition and Growth (RIING) Nutrient Database. The student $t$-test was used to compare selected nutrient content of meals served at both school feeding programmes. Macronutrients of school meals were compared with recommendations of World Food Programme based on $35-45 \%$ of energy intakes for energy and $30 \%$ of intakes for proteins and fats $[9,10]$. Selected micronutrient recommendations were also based on $30 \%$ of dietary reference intakes set by FAO for primary school age $[10,11]$. Dietary diversity scores (DDS) were also calculated using the FAO guideline [12]. Level of significance was set at $p<0.05$.

\section{RESULTS}

\section{Description of School Feeding Programmes}

Attributes of the two types of feeding programmes assessed are summarised in Table 1. At the time of the study the NGSFP, which was inaugurated in May 2012, was managed by Prembaf, a non-governmental organisation, under its Food for the People (FFP) project. The objective of the Prembaf school feeding programme was to provide one healthy meal a day to school children as a means for increasing school attendance and performance. The cost of meal per child was 70 pesewas ( $\$ 0.36$ in 2013). The programme was delivered through a well-resourced (with staff and equipment including plates and utensils for eating) kitchen and dining facility located close to school. The facility served a mid-morning meal (at 10:00 am) for younger children (from kindergarten to primary 5 ) and a lunch meal at 12 noon for older children (from primary level 6 to Junior Secondary School level) on school days and one non-school day, Saturdays. Usually the same meal was served for mid-morning and lunch meal times. The facility also made special provisions for children with known food allergies who could not eat the regular meal provided on any day.

Although GSFP was launched in 2005, it was started at the selected public school in January, 2012. The programme provided a mid-morning meal at a cost 
Table 1: Description of Two School Feeding Programmes in Ghana, 2013

\begin{tabular}{|c|c|c|}
\hline Attributes & NGSFP $^{1}$ & GSFP $^{2}$ \\
\hline Year of Establishment & May, 2012 & January, 2012 \\
\hline Type of meal & Midmorning/Lunch & Midmorning \\
\hline Cost of meal/child & 70 pesewas $(\$ 0.36$ in 2013$)$ & 40 pesewas $(\$ 0.21$ in 2013$)$ \\
\hline Place meals are served & Dining hall & On school block veranda \\
\hline Location for eating meals & Dining hall & No designated area \\
\hline Type of Bowls & Standardised bowls provided & $\begin{array}{l}\text { Each child brings his/her bowl except for kindergarten } \\
\text { children who are provided with bowls }\end{array}$ \\
\hline
\end{tabular}

${ }^{1}$ NGSFP Non-government School Feeding Programme.

${ }^{2}$ GSFP Ghana School Feeding Programme.

of 40 pesewas ( $\$ 0.21$ in 2013) per child. The programme had four staff members who fed children in kindergarten up to Primary 6 . Meals were served on a veranda and children sit anywhere on the school compound including under trees to eat the food. Whereas children in kindergarten were provided bowls for meals, others (primary 1-6) had to bring their own bowls or forfeit meal.

The menus for both sites are shown in Tables 2 and 3. Some of the meals served to the children were: tomato stew (sauce made from tomatoes, oil, pepper and onion); waakye (made of rice, beans and dried millet leaves for colour); jollof (rice cooked in tomatoes sauce); banku (fermented corn flour with cassava cooked into a thick pap); kenkey (fermented corn meal cooked into a thick pap); light soup (prepared with tomatoes, pepper, onions and eggplant; and gari eba (dried cassava flour grits soaked in hot water to become thick pap). When the menu is compared with meals served within the 4 week period (Table 2), it can be observed that beans and gari (dried cassava flour grits with beans sauce) originally on the menu was never served. Informal discussion with the caterer in charge of GSFP indicated that seasonal variability was the main reason for not serving that meal. According to the caterer palm oil, a source of vitamin A was very expensive and will raise the cost of feeding per child more than the money the government hadgiven to cater for school meal. However, the NGSFP manager indicated they do not have a fixed menu. The menu is prepared each week and takes into consideration seasonal availability of food.

\section{Nutrient Content of Meals}

Dietary diversity scores (DDS) for GSFP meal was $3.2 \pm 0.4$ and NGSFP meal was $3.2 \pm 0.4$ based on 9

Table 2: Original Weekly Menu Versus Actual Menu of Ghana School Feeding Programme

\begin{tabular}{|c|c|c|c|c|c|}
\hline \multirow{2}{*}{ Day } & \multirow{2}{*}{$\begin{array}{c}\text { Original } \\
\text { Menu }\end{array}$} & \multicolumn{4}{|c|}{ Actual Menu Observed } \\
\hline & & Week 1 & Week 2 & Week 3 & Week 4 \\
\hline Monday & $\begin{array}{c}\text { Rice and Tomato } \\
\text { stew or Palava } \\
\text { sauce }\end{array}$ & $\begin{array}{l}\text { Rice and Tomato } \\
\text { stew anchovies }\end{array}$ & $\begin{array}{c}\text { Rice and Tomato } \\
\text { stew } \\
\text { anchovies }\end{array}$ & $\begin{array}{c}\text { Rice and Tomato } \\
\text { stew } \\
\text { anchovies }\end{array}$ & $\begin{array}{c}\text { Rice and Tomato } \\
\text { stew } \\
\text { anchovies }\end{array}$ \\
\hline Tuesday & $\begin{array}{l}\text { Waakye and Tomato } \\
\text { stew anchovies }\end{array}$ & $\begin{array}{c}\text { Waakye and Tomato } \\
\text { stew } \\
\text { Anchovies }\end{array}$ & $\begin{array}{l}\text { Waakye and Tomato } \\
\text { stew anchovies }\end{array}$ & $\begin{array}{l}\text { Waakye and Tomato } \\
\text { stew anchovies }\end{array}$ & $\begin{array}{l}\text { Waakye and } \\
\text { Tomato stew } \\
\text { anchovies }\end{array}$ \\
\hline Wednesday & Beans and Gari & Jollof and anchovies & Jollof and anchovies & Jollof and anchovies & $\begin{array}{l}\text { Jollof and } \\
\text { anchovies }\end{array}$ \\
\hline Thursday & $\begin{array}{c}\text { Banku } \\
\text { Okra or palmnut } \\
\text { soup and dried fish }\end{array}$ & $\begin{array}{l}\text { Banku } \\
\text { Okra soup and } \\
\text { anchovies }\end{array}$ & Jollof and anchovies & $\begin{array}{c}\text { Banku } \\
\text { Okra and anchovies }\end{array}$ & $\begin{array}{l}\text { Banku and Tomato } \\
\text { stew anchovies }\end{array}$ \\
\hline Friday & Jollof and anchovies & Jollof and anchovies & $\begin{array}{l}\text { Banku } \\
\text { Okra soup and } \\
\text { anchovies }\end{array}$ & Jollof and anchovies & $\begin{array}{l}\text { Jollof and } \\
\text { anchovies }\end{array}$ \\
\hline
\end{tabular}

Tomato stew is a tomato sauce (tomatoes, oil, pepper and onion); Waakye is made of rice; beans and dried millet leaves; Jollof is rice cooked in tomatoes sauce; Banku is a fermented corn flour and blended cassava (yuca); ${ }^{1}$ for all meals, some children received 5-6 grams of anchovies, others did not receive any whole pieces. 
Table 3: Menu Observed at Non-Government School Feeding Programme in Ghana

\begin{tabular}{|c|c|c|c|c|}
\hline Day & Week 1 & Week 2 & Week 3 & Week 4 \\
\hline Monday & $\begin{array}{l}\text { Rice tomato stew and } \\
\text { Sausage }\end{array}$ & $\begin{array}{l}\text { Rice tomato stew and } \\
\text { Sausage }\end{array}$ & $\begin{array}{c}\text { Rice, tomato stew and } \\
\text { egg }\end{array}$ & $\begin{array}{l}\text { Rice, tomato stew and } \\
\text { Sausage }\end{array}$ \\
\hline Tuesday & $\begin{array}{l}\text { Gari Eba, light soup and } \\
\text { chicken }\end{array}$ & $\begin{array}{l}\text { Gari Eba, light soup and } \\
\text { chicken }\end{array}$ & $\begin{array}{c}\text { Rice, tomato stew and } \\
\text { sausage }\end{array}$ & $\begin{array}{c}\text { Yam with cabbage stew } \\
\text { and Tuna }\end{array}$ \\
\hline Wednesday & $\begin{array}{l}\text { Ga Kenkey, hot pepper } \\
\text { and fried fish }\end{array}$ & $\begin{array}{l}\text { No food served because } \\
\text { of gas shortage }\end{array}$ & $\begin{array}{l}\text { Banku, light soup and } \\
\text { chicken }\end{array}$ & $\begin{array}{l}\text { Ga Kenkey, hot pepper } \\
\text { and fried fish }\end{array}$ \\
\hline Thursday & $\begin{array}{c}\text { Waakye, tomato stew and } \\
\text { sausage }\end{array}$ & $\begin{array}{c}\text { Rice, tomato stew and } \\
\text { egg }\end{array}$ & $\begin{array}{c}\text { Yam, cabbage stew with } \\
\text { Tuna }\end{array}$ & $\begin{array}{l}\text { Waakye, tomato stew } \\
\text { and boiled egg }\end{array}$ \\
\hline Friday & $\begin{array}{l}\text { Banku, light soup and } \\
\text { fried fish }\end{array}$ & $\begin{array}{l}\text { Banku, light soup and } \\
\text { fried fish }\end{array}$ & $\begin{array}{c}\text { Gari eba, light soup and } \\
\text { chicken }\end{array}$ & $\begin{array}{c}\text { Gari eba, light soup and } \\
\text { chicken }\end{array}$ \\
\hline
\end{tabular}

Tomato stew is a tomato sauce (tomatoes, oil, pepper and onion). Kenkey is a fermented corn meal; Banku is a fermented corn flour and blended cassava (yuca). Light soup is sauce prepared with tomatoes, pepper, onions and eggplant. Gari eba (dried cassava flour grits soaked in hot water to become thick pap).

food groups proposed by FAO [12]. Protein portion (anchovies) in GSFP was small. Some children in GSFP did not receive anchovies, whereas, all meals served by NGSFP had a protein portion. The energy and nutrient contents of weighed samples of food served to children in the GSFP and the NGSFP are summarised in Tables $\mathbf{4}$ and $\mathbf{5}$. The portion size of the GSFP meal served to the school age children was significantly lower than that of the NGSFP $(243 \pm 50$ vs. $416 \pm 96 \mathrm{~g}, \mathrm{p}=0.007)$.

The meals served to children in the NGSFP met the World Food Programme's recommendations for energy

Table 4: Nutrient Content of 5-Day Menu of School Meals of GSFP and NGSFP

\begin{tabular}{|c|c|c|c|c|c|c|c|c|c|c|c|}
\hline & \multirow{2}{*}{ Day } & \multirow{2}{*}{ Menu } & \multirow{2}{*}{$\begin{array}{l}\text { Portion } \\
\text { size (g) }\end{array}$} & \multirow{2}{*}{$\begin{array}{c}\text { Energy } \\
\text { (kcal) }\end{array}$} & \multirow{2}{*}{$\begin{array}{l}\text { Protein } \\
\text { (g) }\end{array}$} & \multirow{2}{*}{$\begin{array}{l}\text { Fats } \\
(\mathrm{g})\end{array}$} & \multirow{2}{*}{$\begin{array}{l}\text { Iron } \\
\text { (mg) }\end{array}$} & \multirow{2}{*}{$\begin{array}{l}\text { Zinc } \\
(\mathrm{mg})\end{array}$} & \multirow{2}{*}{$\begin{array}{c}\text { Calcium } \\
(\mathrm{mg})\end{array}$} & \multicolumn{2}{|c|}{ Vitamin } \\
\hline & & & & & & & & & & $A(\mu g)$ & $C(\mathrm{mg})$ \\
\hline \multirow{5}{*}{${ }^{1}$ GSFP } & $M$ & $\begin{array}{c}\text { Rice and } \\
\text { Tomato stew }\end{array}$ & 273 & 353 & 6.38 & 4.68 & 3.98 & 1.11 & 22.0 & 40.5 & 7.8 \\
\hline & $\mathrm{T}$ & $\begin{array}{l}\text { Waakye and } \\
\text { Tomato stew }\end{array}$ & 234 & 302 & 5.87 & 4.58 & 2.78 & 1.11 & 39.2 & 40.5 & 7.8 \\
\hline & w & $\begin{array}{l}\text { Jollof with } \\
\text { anchovies }\end{array}$ & 186 & 290 & 8.7 & 7.61 & 3.5 & 1.18 & 46.3 & 39.1 & 8.54 \\
\hline & $\mathrm{R}$ & $\begin{array}{c}\text { Banku } \\
\text { Okra Soup } \\
\text { with } \\
\text { anchovies }\end{array}$ & 310 & 312 & 10.4 & 3.66 & 8.54 & 2.22 & 70.0 & 2.52 & 9.72 \\
\hline & $\mathrm{F}$ & $\begin{array}{l}\text { Jollof and } \\
\text { anchovies }\end{array}$ & 210 & 319 & 6.3 & 7.77 & 3.55 & 1.07 & 22.3 & 44.1 & 10.3 \\
\hline \multirow{5}{*}{${ }^{2} \mathrm{NGSFP}$} & M & $\begin{array}{l}\text { Rice, tomato } \\
\text { stew and egg }\end{array}$ & 370 & 486 & 11.6 & 9.97 & 5.29 & 1.69 & 45.5 & 110 & 11.7 \\
\hline & $\mathrm{T}$ & $\begin{array}{l}\text { Rice, tomato } \\
\text { stew and } \\
\text { sausage }\end{array}$ & 355 & 482 & 9.53 & 10.6 & 5.04 & 1.55 & 31.9 & 59.7 & 11.4 \\
\hline & w & $\begin{array}{l}\text { Banku, light } \\
\text { soup and } \\
\text { chicken }\end{array}$ & 524 & 783 & 38.4 & 26.3 & 6.78 & 4.44 & 54.8 & 47.3 & 3.5 \\
\hline & $\mathrm{R}$ & $\begin{array}{c}\text { Yam, } \\
\text { cabbage stew } \\
\text { with Tuna }\end{array}$ & 316 & 623 & 8.33 & 11.3 & 1.13 & 0.83 & 44.0 & 7.8 & 40.2 \\
\hline & $F$ & $\begin{array}{l}\text { Rice, tomato } \\
\text { stew and egg }\end{array}$ & 513 & 1507 & 33.5 & 24.6 & 6.87 & 5.43 & 168 & 44.9 & 31.9 \\
\hline
\end{tabular}

${ }^{1}$ GSFP Ghana School Feeding Programme. ${ }^{2}$ NGSFP Non-government School Feeding Programme.Tomato stew is a tomato sauce (tomatoes, oil, pepper and onion). Waakye is made of rice, beans and dried millet leaves. Jollof is rice cooked in tomatoes sauce. Banku is a fermented corn flour and blended cassava (yuca). Light soup is sauce prepared with tomatoes, pepper, onions and eggplant. Gari eba is dried cassava flour grates soaked in hot water.

Days: M-Monday, T-Tuesday, W-Wednesday, R-Thursday, F-Friday. 
Table 5: Energy, Macronutrient and Selected Micronutrient Content of GSFP and NGSFP Meals Compared to World Food Progamme Recommendations

\begin{tabular}{|c|c|c|c|c|}
\hline & ${ }^{1}$ WFP & ${ }^{2}$ GSFP & ${ }^{3}$ NGSFP & ${ }^{4} P$ \\
\hline Portion size (g) & & $243 \pm 50$ & $416 \pm 96$ & 0.007 \\
\hline Energy (kcal) & $555-830$ & $315 \pm 24$ & $776 \pm 427$ & 0.042 \\
\hline Protein (g) & 13.8 & $8 \pm 2$ & $20 \pm 14$ & 0.087 \\
\hline Fats $(\mathrm{g})$ & 10.5 & $6 \pm 2$ & $17 \pm 8$ & 0.019 \\
\hline Iron (mg) & $2.4-3.0$ & $4 \pm 2$ & $5 \pm 2$ & 0.717 \\
\hline Zinc (mg) & $1.5-2.4$ & $1.3 \pm 0.5$ & $3 \pm 2$ & 0.158 \\
\hline Calcium (mg) & $240-390$ & $40 \pm 20$ & $69 \pm 56$ & 0.309 \\
\hline Vitamin A $(\mu \mathrm{g})$ & $120-180$ & $33 \pm 17$ & $54 \pm 37$ & 0.291 \\
\hline Vitamin C (mg) & $7.5-13.5$ & $9 \pm 1$ & $20 \pm 16$ & 0.155 \\
\hline
\end{tabular}

Values are Mean \pm SD; ${ }^{1}$ WFP World Food Programme. ${ }^{2}$ GSFP Ghana School Feeding Programme. ${ }^{3}$ NGSFP Non-government School Feeding Programme. ${ }^{4} \mathrm{P}$ value of $<0.05$ was considered significant.

and macronutrient content; however, those in the GSFP did not (Table 5). Despite the differences in portion sizes, micronutrient content of meals were not significantly different from each other and were nearly similar (Table 5).

\section{DISCUSSION}

This present study found differences in menu and nutritive value of meals at feeding sites. Whereas the GSFP had a fixed menu with one of the menu item never served during the study period, NGSFP did not have a fixed menu. In Ghana, there is not a fixed national menu for school feeding programmes [10]. Menus are prepared at each district level with the help of the Nutrition Officer from the Ghana Health Service in the district [10]. Thus menus differ from one district to the other. In other African countries such as Botswana, South Africa, Nigerian Osun State, there are similar menus nationwide or statewide [10, 13, 14]. Flexible menus that consider seasonal variability and community food sources may be ideal for meeting nutritional needs of school children. The differences in menu that was observed in this study despite both programmes being in the same district may be attributed to the differences in programme and caterers: GSFP versus NGSFP. Meals served by programmes in this study were typical of school feeding meals in Ghana in general, a carbohydrate portion which was either yam, rice, cassava or corn based meal of a stew with vegetables and a protein source [10].

Logistic support for GSFP includes kitchen for cooking, dining hall, bowls for serving meals to children, portable water and storage facilities and latrines [15]. The GSFP as observed in our study had no dining hall but the NGSFP had a dining hall. It is surprising that even in 2013, after nearly 8 years of implementing the GSFP (School feeding programme at the study site was started in January 2012), the school did not have a dining hall. Two studies in Ghana found schools did not have logistic support [15, 16]. Additionally, Sulemana and colleagues reported irregular meetings of implementing committees and sporadic payment of cooks [16].

There are limited studies comparing nutrient content of meals served by GSFP to WFP recommendations. The mean energy content of meals served by GSFP in three schools participating in programme at Ashanti Region was reported to be $460.4 \pm 30.1 \mathrm{kcal}$ [17] which was higher than what was observed in the present study (315 \pm 24 kcal). Similarly, Danquah and colleagues also found that GSFP meals did not meet any of the energy and macronutrient requirements that have been set by $\mathrm{WHO}$ and $\mathrm{FAO}$, this was also observed in our study. In a review of nutritional value of school meals in Accra using linear modeling based on price of food ingredients, it was reported that energy was $534.48 \pm 94.39 \mathrm{kcal}$, proteins $11.03 \pm 4.38 \mathrm{~g}$, fats $19.95 \pm 6.02 \mathrm{~g}$, iron $3.38 \pm 2.67 \mathrm{mg}$ and vitamin $A$ was $15.42 \pm 18.19 \mu \mathrm{g}$ [18]. Parish and Gelli [18] found a higher energy content than the present study and met proteins contributions of children. We need to keep in mind the analyses were based on yearly prices of food ingredients; whereas, the current study weighed what was actually on the plate of school children. The energy content of meals served to primary pupils in Osun state of Nigeria was higher than meals served 
under the Ghana School Feeding Programme (772 \pm $129 \mathrm{kcal}$ vs. $315 \pm 24 \mathrm{kcal})$ in the present study but similar to NGSFP $(772 \pm 129 \mathrm{kcal}$ vs. $776 \pm 427 \mathrm{kcal})$.

There were no significant differences between micronutrient content of NGSFP and GSFP. This was quite surprising considering the vast difference in portion size of meals served by the two programmes. Similar mean dietary diversity scores $(3.2 \pm 0.4)$ and food groups may account for the non-significant differences in micronutrients. WFP recommends that school meals should contain at least four food groups or multi-fortified foods to stabilise or reduce undernutrition among school children [19]. Despite the non-significant differences between micronutrient content of these meals, iron and zinc contents were nearly within limits for recommendations [11]. Calcium and vitamin A contents were fairly lower than a minimum requirement of $30 \%$ for all school feeding programmes. Vitamin A and iron content has been found to be very low in school feeding meals in Ghana [18]. Similarly, micronutrients such as vitamin C, iron, zinc and calcium have been found to be lower than $30 \%$ of nutrient requirement of children in Osun state of Nigeria [20]. Osun [14] found zinc content of school meals in Nigeria to be lower than $30 \%$ of children's intake. Even in South Africa that most schools (9 out of 10 involved in the study) supplied a higher energy than what was observed in the Ghana study, micronutrient content of zinc and iron were not much different [13]. The GSFP is doing its best to meet nutritional needs of school children with limited resources; however, there still needs to be improvement in the both macronutrients and micronutrients supplied to children to ensure adequacy.

\section{CONCLUSION}

To the best of our knowledge, this was the first study in Ghana that examined two feeding-schemes in Ghana, NGSFP and GSFP. The study has another strength of using actual meals served and eaten by school children in nutrient analysis; however, school menus may not always be followed due to seasonal variability of some food commodities. The sample of two schools, one each for the programme in a single District in Greater Accra Region of Ghana limits the generalisability of information to all feeding programmes in Ghana. Albeit, these programmes are similar in the southern regions since they do not receive WFP support.

\section{RECOMMENDATIONS}

Further research should focus on assessing nutrient content of menus in a calendar year to ascertain effects of seasonal availability on nutrient content of meals and explore the relationship between less leftovers and quantity of meals served. Recommendations of energy content of school meals is set at $30-45 \%$ of dietary intakes for school children. Meals provided by GSFP did not meet any of the macronutrients recommendations set by World Food Programme, NGSFP on the other hand met these recommendations. It is essential to review the quantity of meals served by GSFP so as to ensure adequacy of diets. Efforts such as increasing the funding of GSFP meals may be necessary in order to provide quantity and quality meals which meet the calorie and nutrient needs of growing children.

\section{ACKNOWLEDGEMENTS}

This work was partially funded by Prembaf Ghana, an affiliate of Prem Rawat Foundation. The authors thank Prof. Anna Lartey for granting permission to use RIING Nutrient Database, Dr. Seth Adu-Afarwuah, Mr. Boateng Bannerman and Phinehas Adjei for their contribution to data collection and management.

\section{REFERENCES}

[1] Best C, Neufingerl N, Van Geel L, van den Briel T, Osendarp $\mathrm{S}$. The nutritional status of school-aged children: why should we care? Food \& Nutrition Bulletin 2010; 31(3): 400-417. http://dx.doi.org/10.1177/156482651003100303

[2] Fentiman A, Hall A, Bundy D. Health and cultural factors associated with enrolment in basic education: a study in rural Ghana. Soc Sci Med 2001; 52(3): 429-439. http://dx.doi.org/10.1016/S0277-9536(00)00152-0

[3] GSS G, Macro I. Ghana demographic and health survey 2008. Accra, Ghana: Ghana Statistical Service, Ghana Health Service, and ICF Macro 2009.

[4] Drake L, Maier C, Jukes M, Patrikios A, Bundy D. School-age children: their nutrition and health. SCN news 2002; 25: 4-30.

[5] World Food Programme. WFP and School Meals. 2015; [cited 2015 September 2] Available from: http://www.wfp.org/ school-meals/wfp-school-meals.

[6] Kristjansson B, Petticrew M, MacDonald B, Krasevec J, Janzen L, Greenhalgh T, et al. School feeding for improving the physical and psychosocial health of disadvantaged students. The Cochrane Library 2007. http://dx.doi.org/10.1002/14651858.cd004676.pub2

[7] Ghana School Feeding Programme. Snapshot of Ghana school feeding. 2010; [cited 2015 August 30]. Available from: http://hgsf-global.org/en/bank/downloads/doc details/63snapshot-of-ghana-school-feeding

[8] Galloway R. Developing rations for home grown schoo feeding HGSF Working Paper Series \#3. 2010; [cited 2015 July 25] Available from: http://hgsf-global.org/en/ rpublications/173-hgsf-working-paper-series-3-developingrations-for-home-grown-school-feeding.

[9] World Food Programme. Basic guide: School feeding. 2011; [cited 2015 June 2] Available from: http://www.docstoc.com/ docs/85813413/Proposal-for-School-Feeding-Project-Wfp. 
[10] Bhatia R. Operational Guidance on Menu Planning HGSF working paper series. 2013; [cited 2015 August 25] Available from: http://hgsf-global.org/en/bank/downloads/doc download/347-operational-guidance-on-menu-planning.

[11] Food and Agriculture Organization. Dietary Reference Intakes. 2004; [cited 2015 June 30] Available from: http://www.sochinut.cl/pdf/Recomendaciones/DRISummaryLi sting.pdf.

[12] Kennedy G, Ballard T, Dop MC. Guidelines for measuring household and individual dietary diversity. Food and Agriculture Organization of the United Nations; 2011.

[13] Nhlapo N, Lues RJ, Kativu E, Groenewald WH. Assessing the quality of food served under a South African school feeding scheme: A nutritional analysis. S Afr J Sci 2015; 111(1-2): 01-09.

[14] Agbon C, Onabanjo O, Okeke E. Daily nutrient contribution of meals served in the home grown school feeding of Osun State, Nigeria. Nutr Food Sci 2012; 42(5): 355-361. http://dx.doi.org/10.1108/00346651211266872

[15] World Food Programme. Home-Grown School Feeding field case study: Ghana. 2007; [cited 2015 August 07] Available from: http://documents.wfp.org/stellent/groups/public/ documents/newsroom/wfp207421.pdf.
[16] Sulemana M, Ngah I, Majid MR. The challenges and prospects of the school feeding programme in Northern Ghana. Development in Practice 2013; 23 (3): 422-432. http://dx.doi.org/10.1080/09614524.2013.781127

[17] Danquah A, Amoah A, Steiner-Asiedu M, Opare-Obisaw C. Nutritional status of participating and non-participating pupils in the Ghana School Feeding Programme. Journal of Food Research 2012;1(3): 263. Incomplete!

[18] Parish A, Gelli A. What's actually on the plate? A review of the nutritional value of school meals in Western Africa and a linear modeling analysis of school meal menus in Ghana. 2013; [cited 2015 July 19] Available from: http://hgsfglobal.org/en/bank/downloads/doc_download/460-hgsfworking-paper-9-whats-actually-on-the-platea-review-ofnutritional-value-ghana-school-meals-.

[19] World Food Programme. Revised school feeding policy. 2013; [cited 2015 August 31] Available from: http://documents.wfp.org/stellent/groups/public/documents/co mmunications/wfp263529.pdf.

[20] Falade OS, Otemuyiwa I, Oluwasola O, Oladipo W, Adewusi SA. School Feeding Programme in Nigeria: The Nutritional Status of Pupils in a Public Primary School in Ile-lfe, Osun State, Nigeria. Food and Nutrition Sciences 2012; 3(05): 596. http://dx.doi.org/10.4236/fns.2012.35082

(C) 2016 Owusu et al.; Licensee Lifescience Global.

This is an open access article licensed under the terms of the Creative Commons Attribution Non-Commercial License (http://creativecommons.org/licenses/by-nc/3.0/) which permits unrestricted, non-commercial use, distribution and reproduction in any medium, provided the work is properly cited. 